\title{
MEASURING SOCIAL ACCOUNTABILITY OF MEDICAL UNIVERSITIES' EDUCATION FUNCTION- DESIGN, DEVELOPMENT, AND VALIDATION OF INSTRUMENT
}

\author{
Shahram Yazdani1, Maryam Akbarilakeh², Mohamed Elhassan Abdalla3 , Boelen Charles ${ }^{4}$, Azizollah Arbabisarjou ${ }^{5}$, \\ Hossein Karimi Moonaghi ${ }^{6}$
}

${ }_{1}^{1}$ Professor, Department of Medical Education, School of Management and Medical Education, Shahid Beheshti University of Medical Sciences, Tehran, Iran.

${ }^{2}$ Assistant Professor, Department of Medical Education, School of Management and Medical Education, Shahid Beheshti University of Medical Sciences, Tehran, Iran.

${ }^{3}$ Assistant Professor, College of Medicine, and Medical Education Center, University of Sharjah, Sharjah, United Arab Emirates.

${ }^{4}$ Professor, International consultant in health systems and personel, Former WHO (Geneva) Program Coordinator in human resources for health.

${ }^{5}$ Associate Professor, Department of nursing management, Zahedan University of Medical Sciences, Zahedan, Iran.

${ }^{6}$ Professor, Department of Medical Education, School of Medicine, Mashhad University of Medical Sciences, Mashhad, Iran.

\section{BACKGROUND}

ABSTRACT

According to World Health Organization (WHO) emphasis, medical universities should adapt education, research, and service activities to prioritise health needs and challenges of society. To meet education, research, and service responsibilities to society, medical universities should subject themselves to measurement and assessment. Design, development and validation of a measurement instrument for Iranian Medical Schools' social accountability education function is the aim of study. This instrument is designed and developed to measure quality of education related activities within the accreditation of Iranian medical universities.

\section{METHODS}

This is a psychometric study, to develop the first draft of systematized instrument. Comprehensive literature review of resources, university sites, pre-existing scales, and valid universal metrics were used to extract initial items (questions) and to provide the theoretical support for the initial item pool. The theoretical analysis of the first draft would be done by assessing the face and content validity of the new instrument during the two rounds of Delphi technique for instrument validation.

\section{RESULTS}

Eighty-two items included nine dimensions and were developed and validated after two rounds using the Delphi method. Nine dimensions include: Anticipation of Society's Health Needs on the mission and goals of the program (6 items), planning and managing university activities (12 items), educational research (6 items), curriculum planning and educational programs (27 items), faculty members / staff (5 items), participation in health services ( 9 items), graduates (7 items), accreditation ( 7 items), admission of entries ( 3 items). The overall content validity index of the instrument based on the content experts that makes consensus, S-CVI of relevancy was equal to 0.93 .

\section{CONCLUSIONS}

Present paper demonstrates new instrument for education function quality judgment of medical universities. To foster the accreditation standards and norms that reflect social accountability is an urgent need. Therefore, educational institutions and universities should be measured and rewarded based on their real status to meet the important health care needs of society.

\section{KEY WORDS}

Social Accountability, Education Function, Instrument Development, Instrument Validation

HOW TO CITE THIS ARTICLE: Yazdani S, Akbarilakeh M, Abdalla ME, et al. Measuring social accountability of medical universities' education function- design, development, and validation of instrument. J. Evolution Med. Dent. Sci. 2019;8(26):2110-2114, DOI: $10.14260 /$ jemds/2019/464

\section{BACKGROUND}

Due to, ongoing changes in the current world, there is a need for strategic thinking and planning in organizations and educational institutions, including medical universities.

'Financial or Other Competing Interest': None.

Submission 16-04-2019, Peer Review 12-06-2019,

Acceptance 18-06-2019, Published 01-07-2019.

Corresponding Author:

Maryam Akbarilakeh

Assistant Professor, Department of Medical Education,

School of Management and Medical Education,

Shahid Beheshti University of Medical Sciences, Tehran, Iran.

E-mail:m.akbari@sbmu.ac.ir

DOI: $10.14260 /$ jemds $/ 2019 / 464$
In order to be aware of the desirability and quality of medical universities' educational activities, it requires its evaluation and monitoring.[1] In this regard, one of the strategic concerns of policy makers at Shahid Beheshti University of Medical Sciences (SBMU) in Iarn is social accountability of education which should be evaluated and assessed accurately. Also, measurement and assessment of it has been emphasized by the World Health Organization (WHO) over the past decade.[2] Social accountability of medical universities means adapt education, research, and service activities to priority health needs and challenges of society. To meet education, research, and service responsibilities to society, medical university needs to its measurement and assessment.[3] 


\begin{tabular}{|c|c|}
\hline \multirow{6}{*}{$\begin{array}{l}\text { Anticipation of } \\
\text { society's health } \\
\text { needs on the } \\
\text { mission and } \\
\text { goals of the } \\
\text { programs }\end{array}$} & $\begin{array}{l}\text { Are social accountability values including (equity, } \\
\text { quality, relevance, cost effectiveness, community } \\
\text { participation and professionalism and etc.) written in } \\
\text { the mission of the University's Strategic Plan? }\end{array}$ \\
\hline & $\begin{array}{l}\text { Have social accountability values been seen in the } \\
\text { mission and vision of the university curriculums? }\end{array}$ \\
\hline & $\begin{array}{l}\text { Does the university do periodically need assessment } \\
\text { project for identifying the indigenous health problems } \\
\text { of the society? }\end{array}$ \\
\hline & $\begin{array}{l}\text { Do medical school's stakeholders and the society } \\
\text { participate in writing the mission and goals of the } \\
\text { university? }\end{array}$ \\
\hline & $\begin{array}{c}\text { Does the university have mechanism for evaluation of } \\
\text { its mission periodically related with the society's } \\
\text { changing health needs? }\end{array}$ \\
\hline & $\begin{array}{c}\text { Does the university run needs-assessment projects for } \\
\text { identifying health service deficiencies? }\end{array}$ \\
\hline \multirow{12}{*}{$\begin{array}{c}\text { Planning and } \\
\text { managing } \\
\text { university } \\
\text { activities }\end{array}$} & Is the accountability council formed at the university? \\
\hline & $\begin{array}{l}\text { Is a committee or unit specifying to social } \\
\text { accountability of education in development center } \\
\text { (EDC) of university? }\end{array}$ \\
\hline & $\begin{array}{c}\text { Does the university determine the degree of faculty } \\
\text { members' engagement in the fields? }\end{array}$ \\
\hline & $\begin{array}{c}\text { Does the university have a specific program to increase } \\
\text { the motivation of faculty members to conduct social } \\
\text { accountability activities? }\end{array}$ \\
\hline & $\begin{array}{c}\text { Does the university determine the extent of student } \\
\text { activities in society fields? }\end{array}$ \\
\hline & $\begin{array}{c}\text { Does the university have a plan to strengthen and } \\
\text { enhance the educational and research use of society } \\
\text { fields? }\end{array}$ \\
\hline & $\begin{array}{l}\text { Does the university analyse the number and } \\
\text { compositions of clients refer to their clinical services } \\
\text { (Case Mix \& Case Count) for the assessment and } \\
\text { management of clinical education fields? }\end{array}$ \\
\hline & $\begin{array}{l}\text { Does the university have a specific program to assess } \\
\text { the performance of its graduates after graduation? }\end{array}$ \\
\hline & $\begin{array}{l}\text { Are Student Committees Participating in University } \\
\text { Planning? }\end{array}$ \\
\hline & $\begin{array}{l}\text { Does the university have programs, books, training } \\
\text { seminars to meet the needs of society members? }\end{array}$ \\
\hline & $\begin{array}{c}\text { Do the university resources be evaluated according to } \\
\text { the educational program needs? }\end{array}$ \\
\hline & $\begin{array}{l}\text { Do all of the colleges and institutes associated with and } \\
\text { under the supervision of the university move on social } \\
\text { accountability? }\end{array}$ \\
\hline \multirow{6}{*}{$\begin{array}{l}\text { Educational } \\
\text { research }\end{array}$} & $\begin{array}{c}\text { Are topics of thesis related to the needs and health } \\
\text { indicators of the society prioritized as the subject of } \\
\text { specialized thesis in the university? }\end{array}$ \\
\hline & $\begin{array}{l}\text { Does the medical school have availability to local, } \\
\text { regional, and international educational expertise? }\end{array}$ \\
\hline & $\begin{array}{l}\text { Does the university have a policy to develop the } \\
\text { relation between research and teaching? }\end{array}$ \\
\hline & $\begin{array}{l}\text { Does the university research aim the society's high- } \\
\text { priority health needs? }\end{array}$ \\
\hline & $\begin{array}{c}\text { Do research results be used for society health and } \\
\text { health system development? }\end{array}$ \\
\hline & $\begin{array}{c}\text { Do thesis projects of students do with the participation } \\
\text { of people from their future practice? }\end{array}$ \\
\hline \multirow{5}{*}{$\begin{array}{l}\text { Curriculum and } \\
\text { educational } \\
\text { programs }\end{array}$} & $\begin{array}{c}\text { Do the university curriculum committees prioritize } \\
\text { changes in the curriculum and determine the goals of } \\
\text { change based on the results of society needs } \\
\text { assessment? }\end{array}$ \\
\hline & $\begin{array}{l}\text { Do educational departments and groups have precise } \\
\text { plan for Students' Experience in Society fields? }\end{array}$ \\
\hline & $\begin{array}{l}\text { Does the educational program lead to early and } \\
\text { adequate connection with patients for the students? }\end{array}$ \\
\hline & $\begin{array}{c}\text { Does the educational program encourage the } \\
\text { development of positive attitudes, good behaviours and } \\
\text { professionalism? }\end{array}$ \\
\hline & $\begin{array}{l}\text { Do the student assessment methods lead to valid } \\
\text { decisions about the basic competencies of the doctors' } \\
\text { future practice? }\end{array}$ \\
\hline
\end{tabular}

\begin{tabular}{|c|c|}
\hline & $\begin{array}{l}\text { Does the medical school have an appropriate scientific } \\
\text { method for standard setting (cut-off point in the } \\
\text { scoring scale that distinct the incompetent from the } \\
\text { competent students)? }\end{array}$ \\
\hline & $\begin{array}{l}\text { Does the university have a special plan for curriculum } \\
\text { promotion based on society needs? }\end{array}$ \\
\hline & $\begin{array}{l}\text { Does the university have a specific mechanism to } \\
\text { reduce the burden and prevent curriculum overload? }\end{array}$ \\
\hline & $\begin{array}{l}\text { Are the objectives of the course plans set up in aligning } \\
\text { with the social accountability of the curriculum? }\end{array}$ \\
\hline & $\begin{array}{l}\text { Are expected outcomes of students based on society } \\
\text { needs? }\end{array}$ \\
\hline & $\begin{array}{c}\text { Is the current design of educational activities based on } \\
\text { the future task of learners in the society? }\end{array}$ \\
\hline & $\begin{array}{l}\text { Are the teaching strategies aligned with the social } \\
\text { accountability of the curriculum? }\end{array}$ \\
\hline & $\begin{array}{l}\text { Are community-oriented education quality } \\
\text { improvement strategies used in university education? }\end{array}$ \\
\hline & $\begin{array}{c}\text { Do members of the profession community participate } \\
\text { in designing university education programs? }\end{array}$ \\
\hline & $\begin{array}{l}\text { Does the university's educational program address the } \\
\text { needs of all cultures and communities of the society? }\end{array}$ \\
\hline & $\begin{array}{l}\text { Does the university have sufficient physical facilities } \\
\text { such as the PHC facilities to deliver the part of the } \\
\text { curriculum which is conducted in the community? }\end{array}$ \\
\hline & $\begin{array}{c}\text { Do medical students encounter with the community } \\
\text { members they are supposed to serve in their } \\
\text { educational experiences? }\end{array}$ \\
\hline & $\begin{array}{l}\text { Are standard community patients in university medical } \\
\text { education programs used? }\end{array}$ \\
\hline & $\begin{array}{l}\text { Is the suitable time specified for teaching lessons in the } \\
\text { community fields? }\end{array}$ \\
\hline & $\begin{array}{c}\text { Are faculty members from vulnerable and low-income } \\
\text { communities in terms of health services? }\end{array}$ \\
\hline & $\begin{array}{l}\text { Is it defined for clinical faculty members serving in } \\
\text { vulnerable communities? }\end{array}$ \\
\hline & $\begin{array}{l}\text { Have the educational groups determined the goals and } \\
\text { theoretical and practical syllabus for their students' } \\
\text { social accountability education? }\end{array}$ \\
\hline & $\begin{array}{l}\text { Is social accountability education methods used in the } \\
\text { university? }\end{array}$ \\
\hline & $\begin{array}{l}\text { Have the groups determined the social accountability } \\
\text { education methods for educating their students and } \\
\text { have announced them to the accountability committee } \\
\text { at the EDC? }\end{array}$ \\
\hline & $\begin{array}{l}\text { Is attitude of students' medical specialty selection } \\
\text { based on society needs? }\end{array}$ \\
\hline & $\begin{array}{c}\text { Are university curricula regularly reviewed and revised } \\
\text { according to the needs of the community? }\end{array}$ \\
\hline & $\begin{array}{c}\text { Does the educational program notice to the Moral and } \\
\text { Ethical values of the community (right and wrong } \\
\text { behaviours in the community)? }\end{array}$ \\
\hline & $\begin{array}{c}\text { Does educational program aim to teach its graduates as } \\
\text { the community leader and Manager? }\end{array}$ \\
\hline & $\begin{array}{l}\text { Is public social capabilities such as teamwork, } \\
\text { leadership, communication and cultural skills in the } \\
\text { curriculum of all disciplines have been considered? }\end{array}$ \\
\hline & $\begin{array}{c}\text { Does the university have specific faculty empowerment } \\
\text { programs for promoting social accountability } \\
\text { education training and assessment skills? }\end{array}$ \\
\hline & $\begin{array}{c}\text { Does the University have social accountability } \\
\text { programs to empower graduates in continuing } \\
\text { education? }\end{array}$ \\
\hline $\begin{array}{c}\text { Faculty } \\
\text { members /staffs }\end{array}$ & $\begin{array}{l}\begin{array}{c}\text { Does the university have a policy for recruitment and } \\
\text { promotion of the teaching staff? }\end{array} \\
\end{array}$ \\
\hline & $\begin{array}{l}\text { Are the continuing education programs of the } \\
\text { university reviewed and revised according to the needs } \\
\text { of the community? }\end{array}$ \\
\hline & $\begin{array}{c}\text { Does the university have specific faculty empowerment } \\
\text { programs for promoting social accountability } \\
\text { education training and assessment skills? }\end{array}$ \\
\hline
\end{tabular}




\begin{tabular}{|c|c|}
\hline & $\begin{array}{l}\text { Does the university employ the faculty based on their } \\
\text { loyalty and support for the social mission of the } \\
\text { medical university? }\end{array}$ \\
\hline & $\begin{array}{l}\text { Is the university faculty promotion system based on } \\
\text { their loyalty and support for the social mission of the } \\
\text { medical university? }\end{array}$ \\
\hline \multirow{9}{*}{$\begin{array}{l}\text { Participation in } \\
\text { community } \\
\text { health services }\end{array}$} & $\begin{array}{l}\text { Are the university faculty members involved in the } \\
\text { implementation of health services needs projects with } \\
\text { other national or regional educational institutions? }\end{array}$ \\
\hline & $\begin{array}{l}\text { Does the university plan to build relationships with } \\
\text { various stakeholders of educational programs in the } \\
\text { society? }\end{array}$ \\
\hline & $\begin{array}{l}\text { Does the university have a policy for the involvement } \\
\text { of the staff and students in the community's health } \\
\text { development activities? }\end{array}$ \\
\hline & $\begin{array}{c}\text { Does the university have a policy to distinguish and } \\
\text { implement program that progress the health status of } \\
\text { the underserved and at-risk groups? }\end{array}$ \\
\hline & $\begin{array}{c}\text { Does the university have a policy for regularly } \\
\text { evaluating and progressing the services provided to the } \\
\text { community? }\end{array}$ \\
\hline & $\begin{array}{l}\text { Do the community's health activities be related to the } \\
\text { community's health needs? }\end{array}$ \\
\hline & $\begin{array}{l}\text { Does the university organize resources to make } \\
\text { relations with stakeholders in the society? }\end{array}$ \\
\hline & $\begin{array}{l}\text { Does the university have any plan to evaluate the } \\
\text { impact of education on community's health status? }\end{array}$ \\
\hline & $\begin{array}{l}\text { Does the university have any plan to improve the } \\
\text { impact of education on community's health status? }\end{array}$ \\
\hline \multirow{7}{*}{ Graduates } & Do graduates serving in local and small areas? \\
\hline & $\begin{array}{c}\text { Is there attitude of return to the local and small areas } \\
\text { and serving there on university graduates? }\end{array}$ \\
\hline & $\begin{array}{l}\text { Are the specializations selected by university graduates } \\
\text { based on community needs? }\end{array}$ \\
\hline & $\begin{array}{l}\text { Do graduates of the university have a proper } \\
\text { distribution in the private and public sectors? }\end{array}$ \\
\hline & $\begin{array}{l}\text { Do graduates of the university have a proper } \\
\text { distribution in urban and rural areas? }\end{array}$ \\
\hline & \begin{tabular}{|c|} 
Do graduates of the university have a proper \\
distribution of primary, secondary and tertiary services \\
fields?
\end{tabular} \\
\hline & $\begin{array}{c}\text { Does the university have any plan to follow up on their } \\
\text { graduates' performances in the community? }\end{array}$ \\
\hline \multirow{7}{*}{ Accreditation } & $\begin{array}{c}\text { Does the university have a plan for evaluating and } \\
\text { monitoring the process of delivering educational } \\
\text { programs? }\end{array}$ \\
\hline & $\begin{array}{l}\text { Does the university have a plan to assess the } \\
\text { effectiveness of its graduates in the community? }\end{array}$ \\
\hline & $\begin{array}{l}\text { Does the university have a plan to assess the impact of } \\
\text { their educational programs? }\end{array}$ \\
\hline & $\begin{array}{l}\text { Does the university have valid and reliable tools for } \\
\text { measuring social accountability of its programs and } \\
\text { activities? }\end{array}$ \\
\hline & $\begin{array}{c}\text { Is the report on ongoing monitoring of social } \\
\text { accountability accreditation programs at the university } \\
\text { given to the beneficiaries and stakeholders? }\end{array}$ \\
\hline & $\begin{array}{l}\text { Do stakeholders participate in the planning of the } \\
\text { social accountability programs and activities } \\
\text { evaluation? }\end{array}$ \\
\hline & $\begin{array}{c}\text { Does the university have clear program evaluation and } \\
\text { quality assurance about social accountability of the } \\
\text { outcomes, content and process of the educational } \\
\text { programs? }\end{array}$ \\
\hline \multirow{3}{*}{$\begin{array}{l}\text { Admission of } \\
\text { entries }\end{array}$} & $\begin{array}{l}\text { Is the admission of students of each discipline based on } \\
\text { the needs of the community? }\end{array}$ \\
\hline & $\begin{array}{l}\text { Is the number of entries of each discipline based on the } \\
\text { needs of the community? }\end{array}$ \\
\hline & $\begin{array}{c}\begin{array}{c}\text { Does the university have any rule for selecting students } \\
\text { from underserved areas? }\end{array} \\
\end{array}$ \\
\hline
\end{tabular}

\begin{tabular}{|c|c|c|}
\hline Relevancy & Simplicity & Clarity \\
\hline 1 Not relevant & 1 Not simple & 1 Not clear \\
\hline $\begin{array}{c}\text { 1 Partly relevant item } \\
\text { require some revision }\end{array}$ & $\begin{array}{c}\text { 2 Partly simple item } \\
\text { require some revision }\end{array}$ & $\begin{array}{c}\text { 2 Partly clear item } \\
\text { require some revision }\end{array}$ \\
\hline $\begin{array}{c}\text { 3 Relevant but require } \\
\text { minor revision }\end{array}$ & $\begin{array}{c}\text { 3 Simple but require } \\
\text { minor revision }\end{array}$ & $\begin{array}{c}\text { 3 Clear but require } \\
\text { minor revision }\end{array}$ \\
\hline 4 Completely relevant & 4 Completely simple & 4 Completely clear \\
\hline \multicolumn{3}{|c|}{$\begin{array}{r}\text { Table 2. The Table Added to the Cover Letter of 1 } \text { st Draft of } \\
\text { Instrument to Conduct Expert to Score Items }\end{array}$} \\
\hline
\end{tabular}

\begin{tabular}{|c|c|c|c|c|c|}
\hline Dimension & Items & $\begin{array}{c}\text { Rating } \\
\mathbf{3} \text { or 4 } \\
\text { (Relevant) }\end{array}$ & $\begin{array}{c}\text { Rating 1 or 2 } \\
\text { (Not } \\
\text { relevant) }\end{array}$ & I-CVIs * & Description \\
\hline & 1 & 14 & 0 & 1 & Appropriate \\
\cline { 2 - 6 } & 2 & 12 & 2 & 0.857 & Appropriate \\
\cline { 2 - 6 } & 3 & 13 & 1 & 0.928 & Appropriate \\
\cline { 2 - 7 } $\begin{array}{c}\text { Faculty } \\
\text { members } \\
\text { staffs }\end{array}$ & 4 & 11 & 3 & 0.785 & $\begin{array}{c}\text { Require for } \\
\text { Revision }\end{array}$ \\
\cline { 2 - 7 } & 5 & 8 & 6 & 0.571 & Eliminated \\
\cline { 2 - 7 } & 6 & 14 & 0 & 1 & Appropriate \\
\hline
\end{tabular}

Table 3. I-CVI and S-CVI for Items of Faculty Members/Staff

Dimension

\begin{tabular}{|c|c|c|c|}
\hline Dimensions & $\begin{array}{c}\text { Number } \\
\text { giving } \\
\text { Rating of 3 } \\
\text { or 4 to } \\
\text { Relevancy of } \\
\text { Items }\end{array}$ & I-CVI * & Description \\
\hline $\begin{array}{c}\text { D1: Anticipation of Society's } \\
\text { Health Needs on the mission } \\
\text { and goals of the program }\end{array}$ & 15 & 1 & Excellent \\
\hline $\begin{array}{c}\text { D2: Planning and managing } \\
\text { university activities }\end{array}$ & 12 & 0.857 & Excellent \\
\hline D3: Educational research & 13 & 0.928 & Excellent \\
\hline $\begin{array}{c}\text { D4: Curriculum planning and } \\
\text { educational programs }\end{array}$ & 15 & 1 & Excellent \\
\hline D5: Faculty members / staffs & 14 & 1 & Excellent \\
\hline $\begin{array}{c}\text { D6: Participation in health } \\
\text { services }\end{array}$ & 13 & 0.928 & Excellent \\
\hline D7: Graduates & 13 & 0.928 & Excellent \\
\hline D8: Accreditation & 11 & 0.785 & Excellent \\
\hline D9: Admission of entries & 12 & 0.857 & Excellent \\
\hline Table 4. I-CVI, S-CVI for 82 Remaining Items at the Final \\
Instrument & \multicolumn{2}{|l}{} \\
\hline
\end{tabular}

Such as many other universities in the world, measurement and assessment of social accountability of education function in medical universities was determined as a part of strategic program of SBMU. The Steering Committee on measurement and instrument established to design, develop, and validate an instrument for measuring social accountability of education function of SBMU. There were some activities regarding measuring social accountability of medical schools in all university functions. This project focuses on social accountability of education function. Standards and indicators which were developed in previous studies measuring social accountability of medical school's education function were considered. ${ }^{[4]}$ The novelty of this project lies on its instrument development based on comprehensive theoretical support and theoretical analysis for validation of standards based on Delphi method. Design, development and validation of a measurement instrument for Iranian medical schools' social accountability education function is the aim of study. This instrument designed and developed to measure education related activities quality within the accreditation of medical universities. 


\section{METHODS}

This psychometric study was done to design and validate the instrument measuring social accountability of medical universities education function. To develop the first draft of instrument, systematized and comprehensive literature review of resources, university sites, pre-existing scales, and valid universal metrics were used to extract initial items and to provide the theoretical support for the initial item pool. The theoretical analysis of the first draft would be done by assessing the face and content validity of the new instrument during the two rounds of Delphi for instrument validation.

\section{Stage 1: Instrument Design}

To Design and develop the first draft of instrument, systematized and comprehensive literature review of resources, university sites, pre-existing scales, and valid universal metrics were used to extract initial items (questions) and to provide the theoretical support for the initial item pool.[5] The items was designed collaboratively by Abdulla's standards which are extracted from a grounded theory and to measure social accountability of medical schools in the accreditation systems. [4][6] Instrument first draft developed including dimensions that each category of initial items and questions are below of its related dimension. The assignment of initial items and questions to aligned dimension is based on previous studies that were done about social accountability of education. Instrument first draft consists of nine dimensions and related items.

\section{Stage 2: Instrument Validation}

The theoretical analysis of the first draft would be done by assessing the content validity of the new instrument, certify that the initial item pool reflects the required dimension [7] [8] 15 experts are asked to score from 1 to 3 to each item with a three-degree range of: "not necessary, useful but not essential, essential" Content validity ratio changes between -1 and 1 Calculated by CVR. Relevancy; Clarity and also simplicity are calculated. Likert Scaling 1 to 10 is preferred to use for scaling. The theoretical analysis of the first draft was done within the first round of the Delphi, the draft sent to 15 social accountability experts. Then, comments collected and classified for the second Delphi and necessary reforms were implemented in the instrument.

For content validity, content experts' recommendations about using appropriate dimensions, applying proper order of items in each dimension, proper words in items and appropriate scoring were collected.[9]

Experts were asked to determine whether an item is necessary for the specified dimension or not. To this end, they were asked to score each item from 1 to 3 with a three-degree range of "not necessary, useful but not essential, essential" respectively. Content validity ratio changes between 1 and -1 . The higher score demonstrates further agreement of members of experts on the necessity of an item in the instrument. The formula of content validity ratio is $\mathrm{CVR}=(\mathrm{Ne}$ (the number of panellists indicating "essential") - $\mathrm{N}$ (total number of experts)/2)/ ( (total number of experts)/2). The numeric value of content validity ratio is defined by Lawshe Table. For example, in our study with 15 expert members, if CVR is bigger than 0.62 , the item in the instrument with an acceptable level of significance will be accepted.[10]
Experts were requested to rate instrument items in terms of Relevancy; Clarity and also simplicity to the items and its dimensions on a 4-point ordinal scale. A table like the one was shown below (Table 2).

Content validity index (CVI) for relevancy, Simplicity and clarity of each item were determined through the experts judging the item as relevant, simple or clear (rating 3 or 4) was divided by the content experts but for relevancy, content validity index can be calculated both for item level (I-CVIs) and the scale-level (S-CVI). In item level, I-CVI is calculated as the number of experts giving a rating 3 or 4 to the relevancy of each item, divided by the total number of experts.

The I-CVI shows the proportion of agreement on the relevancy of each item, which is between zero and one and the SCVI is as "the proportion of total items judged content valid" or "the proportion of items on an instrument that achieved a rating of 3 or 4 by the content experts".[11]

Table 3 prepares data for better understanding on computation CVI and S-CVI. Data of table has been extracted from judges of our experts about relevancy of items to dimensions. Instrument developers should mention the method used for computing it. Davis offers that researchers should notice 80 percent agreement or higher among judges for new instruments. Judgment on each item is made as: If the I-CVI is higher than 79 percent, the item will be appropriate. If it is between 70 and 79 percent, it needs revision. If it is less than 70 percent, it is eliminated.[12]

\section{RESULTS}

Results of Stage 1: Designing and Developing Social Accountability of Medical Universities Education Function Measuring Instrument

The results led to identifying nine dimensions including eighty-two items. Nine dimensions include: Anticipation of Society's Health Needs on the mission and goals of the program (6 items), Planning and managing university activities (12 items), Educational research (6 items), Curriculum planning and educational programs (27 items), Faculty members / staffs (5 items), Participation in health services (9 items), Graduates (7 items), Accreditation (7 items), Admission of entries (3 items).

Each of the dimensions and their related items was specified theoretically by comprehensive and systematized literature review. In the item generation step, 90 items were developed related to these nine dimensions. The primary instrument was made by 90 items (items pool) within nine dimensions of social accountability of medical universities education function measuring instrument.

\section{Results of Stage 2: Delphi of Experts on Validity of Measuring Instrument}

After selecting 15 content experts containing the instrument developers (four people), social accountability experts (eight people), education related managers as target group experts (three people), an expert panel was built for making judgments on instrument items. The panel member experts were asked through Delphi sessions to judge on content validity ratio, content validity index. In each Delphi round, they were asked to judge on face and content validity of instrument as well. After Delphi rounds, eight items out of 90 instrument items were eliminated. These eliminated items had content validity ratio lower than 0.49 . 
Content validity index of each item was calculated by the number of experts judging the item as relevant was divided by the number of content experts $(\mathrm{N}=15)$. This work was also performed to simplify and clarify the items of the instrument. The agreement between the judges for the whole instrument was only computed for relevancy. Table 4 shows the computation of I-CVI, S-CVI for items in the instrument for 82 remaining items at the end of the two Delphi round.

\section{DISCUSSION}

New instrument was assessed for validity and reliability.[13] For reliability uses internal consistency, item-total correlation/inter-item reliability[14]. Validity and reliability was done for development of acceptable and applied instrument across contexts and produced findings useful to compare medical schools. The instrument would be useful as a formative evaluation to help medical schools take a critical look at their performance and advancement towards social accountability in their education function. It aids in identifying strengths, weaknesses and gaps, with a view to medical schools zealous for continuous self-improvement. It is suggested that all managers related to education function at schools of SBMU to complete instrument for pilot testing and appropriateness analysis of the instrument in Iranian context. It is important to pilot test the instrument to ensure that the questions reliability.

\section{CONCLUSION}

Present paper demonstrates new instrument for medical schools which should be ready to be judged. There is an urgent need to develop the accreditation standards and norms that reflect social accountability. Educational institutions and universities should be measured and rewarded for their real status to meet the important health care needs of society.

\section{REFERENCES}

[1] Marope PTM, Wells PJ, Hazelkorn E. Rankings and accountability in higher education: uses and misuses. UNESCO 2013.

[2] Boelen C, Heck JE. Defining and measuring the social accountability of medical schools. Geneva, Switzerland: Division of Development of Human Resources for Health, World Health Organization, 1995.
[3] Boelen C, Pearson D, Kaufman A, et al. Producing a socially accountable medical school: AMEE Guide No. 109. Med Teach 2016;38(11):1078-91.

[4] Abdalla ME. Suggested New Standards to Measure Social Accountability of Medical Schools in the Accreditation Systems. Journal of Case Studies in Accreditation and Assessment 2014;3.

[5] Kapuscinski AN, Masters KS. The current status of measures of spirituality: a critical review of scale development. Psychology of Religion and Spirituality 2010;2(4):191-205. http://dx.doi.org/10.1037/a0020498.

[6] Boelen C, Woollard B. Social accountability and accreditation: a new frontier for educational institutions. Med Educ 2009;43(9):887-94.

[7] Arias B, Verdugo MA, Navas P, et al. Factor structure of the construct of adaptive behavior in children with and without intellectual disability. International Journal of Clinical and Health Psychology 2013;13(2):155-66.

[8] Nunnally JC, Bernstein IH. Psychometric theory. $3^{\text {rd }}$ edn. New York: McGraw-Hill 1994.

[9] Safikhani S, Sundaram M, Bao Y, et al. Qualitative assessment of the content validity of the Dermatology Life Quality Index in patients with moderate to severe psoriasis. J Dermatolog Treat 2013;24(1):50-9.

[10] Lawshe $\mathrm{CH}$. A quantitative approach to content validity. Personnel Psychology 1975;28(4):563-75.

[11] Waltz C, Bausell BR. Nursing research: design statistics and computer analysis. Philadelphia: Davis FA Publisher 1981: p. 19-29.

[12] Davis LL. Instrument review: getting the most from a panel of experts. Applied Nursing Research 1992;5(4):194-7.

[13] Churchill GA Jr. A paradigm for developing better measures of marketing constructs. Journal of Marketing Research 1979;16:64-73.

[14] DeVellis RF. Scale development: theory and applications Vol. 26. 2nd edn. Thousand Oaks, CA: Sage Publications 2003. 